\title{
How to Assess Whether Qualified Evaluations of e-Government Projects Are Conducted? The Case of Slovenia
}

\author{
Jože Benčina \\ University of Ljubljana, Faculty of Public Administration, Slovenia \\ joze.bencina@fu.uni-lj.si \\ Tina Jukić \\ University of Ljubljana, Faculty of Public Administration, Slovenia \\ tina.jukic@fu.uni-lj.si
}

\section{ABSTRACT}

Countries are investing significant resources in the development of e-government, but evaluations of e-government projects are rarely conducted in a comprehensive way. In order to take the right measures and to be effective in fostering the use and raising the quality of evaluations of e-government projects it is important to reveal the state of the practice. The paper presents the results of the research based on identification of parameters required to be measured in order to conduct qualified evaluations of e-government projects. Thirteen such paramaters were identified via the focus group, with participants comprising (Slovenian) e-government decision-makers and researchers. Using these 13 parameters and 7 additional questions about the knowledge and use of evalution methods a questionnaire was designed and applied in a survey on Slovenian public administration. Employing a binomial test and Fisher's combined probability test it was established that in Slovenian public administration qualified evaluations of e-government projects were not being conducted. The method has demonstrated an eligible usability both for analysing the general situation and for exposing opportunities for improvement in various specific situations.

Keywords: e-government, e-government project, evaluation, methodolgy

$J E L: K 40$

\section{Introduction}

Over the past 15 years, there has been put an enormous effort into the development of e-government. This is due to the fact that e-government has become one of the priority fields within the national (and international) development strategies (e.g. EU Action plan, Slovenian Strategy). Therefore, 
it is not surprising that countries have invested significant resources in the development of e-government services.

Nevertheless, despite significant resources being invested in the development of e-government (Castelnovo \& Simonetta, 2007; eGEP, 2006a; Heeks, 2012), decisions on how these resources should be spent or which services should have priority in the development and implementation thereof have not (always) been well-grounded. A number of projects in e-government were the result of lobbying (Kertesz, 2003; Yildiz, 2007) or of "copying" other organizations; in some cases, such decisions were simply made ad hoc (Datar, 2010) - even though the literature suggests that proper planning is one of the key success factors in successful e-government implementation (Rana, Dwivedi, \& Williams, 2013).

Therefore, some countries have already developed their own methodologies for evaluating e-government projects. Also, this topic has attracted a lot of attention in research (Jukić \& Benčina, 2015; Stanimirović, Jukić, Nograšek, \& Vintar, 2014; Todorovski, Jukić, Leben, \& Vintar, 2014; Nograšek, Stanimirović, Jukić, \& Vintar, 2012). Some of these approaches encompass over a hundred parameters of evaluation (different categories of costs, benefits, risks etc.). Methodologies with so many parameters possibly make sense in countries with a highly-developed evaluation culture. But the same does not hold true for countries where evaluation has not yet become an equally important phase of the project cycle, nor for the countries where project management mechanisms have not beent fully in place yet. These countries may use a narrower set of parameters in their initial evaluations of e-government projects - as much as necessary for a qualified evaluation. Besides that, the raising of awarness must be supported by a clear insight into the state in the field of evaluation of e-government projects. For this end a simple and efficient tool for the assessment of the general situation and for the exposition of the opportunities for improvment in different subfields or specific e-government projects is needed.

The research question addressed in this paper is: Are qualified evaluations of e-government projects carried out in Slovenian public administration? In this regard, four objectives have been pursued:

1. to present the existing approaches to the evaluation of e-government projects;

2. to define the parameters required for qualified evaluation of e-government projects;

3. to define the questionnaire for the assessment of the status quo regarding qualified evaluation of e-government projects,

4. to conduct a survey on the state in the field of qualified evaluations of e-governemnt projects in the Slovenian public administration. 
In the next chapter, a theoretical background of evaluation is given, followed by a chapter which presents the research methodology. In the fourth chapter, the results of the research are presented. In the last chapter, the final conclusions are summarized.

\section{About Evaluation}

Based on Owen's (Thomas, Seddon, \& Fernandez, 2008, p. 79) definition of evaluation, we similarly define evaluation of e-government projects as the process of providing information in order to support decision-making on the realization/implementation of the services.

The literature provides a range of typologies of evaluation, e.g. according to time, driver, and subject of evaluation, as well as level of its aggregation. For the purpose of this paper, typology according to the time in which an evaluation is to be conducted is of crucial importance. From this point of view, we draw a distinction between ex-ante and ex-post evaluation. When conducting ex-ante evaluation, we tend to evaluate all potential alternative solutions and their effects (Kustec Lipicer, 2002). Thus, the purpose of ex-ante evaluation is to make a forecast (Remenyi, 1999), mainly on the basis of the anticipated costs, benefits, effects, opportunities, and challenges (Homburg, 2008). Ex-ante evaluation is of a much more theoretical nature than ex-post evaluation, which follows the phase of implementation (Pollitt, 2008). The general purpose of ex-post evaluation is to gather and evaluate effects (Kustec Lipicer, 2002), e.g. economic, social or whichever outcomes (Homburg, 2008). Ex-post evaluation may also serve as an important source of feedback for further ex-ante evaluation, ultimately making it more realistic (Cracknell, 2000).

\section{Methodology}

The methodology was designed in accordance with the research objectives in three segments:

- definition of the parameters required for the qualified evaluation of e-government projects,

- definition of the tool for the assessment of the status quo in the evaluation of e-government projects,

- design of the survey on the status quo in Slovenian public administration.

To identify the parameters needing to be measured in order to conduct qualified evaluations, the following steps were undertaken: first, on the basis of literature regarding e-government evaluation and current approaches to evaluating e-government projects, an extended list of potential parameters was prepared. In order to identify the parameters required for qualified ex-ante evaluation of e-government projects, the focus group combined with 
the Delphi method ${ }^{1}$ was conducted with two representatives of the (former) Ministry of Public Administration and two representatives of the Slovenian e-government research area.

Once the parameters of qualified evaluation were identified, a web questionnaire was constructed. The questions were, with the exception of those intended for identifying the respondents' profiles, designed in the form of statements; respondents were asked to express their level of agreement with those statements using a seven-point scale, where 1 represented the lowest level of agreement, and 7 the highest level of agreement with a particular statement. The statments measure respondents' level of agreement with statements related to the measurement of those of the above-mentioned evaluation parameters that were defined as crucial for qualified evaluation, how familiar they are with the methods for evaluating projects, and how common the use of the suitable methods is in practice.

To answer the research question "Are qualified evaluations of e-government projects conducted in Slovenian public administration?" a survey was designed. This way the appropriateness of the survey as the supporting tool for raising awarness and fostering improvement in the qualified evaluation of e-government projects was justified. The previously mentioned web questionnaire was employed as the data-gathering tool. A web survey designed with The Survey System 9.0 was conducted. The sample covered the Slovenian public administration; more precisely, it included 266 organizations, namely:

- 15 ministries;

- 40 bodies affiliated with these ministries; and

- 211 municipalities.

The survey was first tested with seven respondents and modified based on the feedback gathered. Then, invitations were sent via email to the $\mathrm{ClOs}^{2}$ in the case of ministries and their affiliated bodies, and to the directors of the municipal administrations in the case of municipalities. The email included a request to forward the invitation to the organisation's most knowledgeable person on making decisions related to the development and implementation of e-government services offered to citizens and businesses by their organization.

Suitable descriptive statisitics were used for data analysis. The research question was answered by testing the hypothesis. Due to small sample numerous a nonparametric binomial test was employed and to combine

1 The focus group followed consensus building Delphi procedure in four rounds. In the first round, process began with an open-ended questionnaire. In the second step, each Delphi participant rated the parameters. In the third round, each member of the focus group received a questionnaire with parameters and ratings. In the final round, to provide the final opportunity for the revision of judgments, the list of remaining parameters with ratings was distributed to participants.

2 Chief Information Officers. 
the results from several independent tests bearing upon the same overall hypothesis ( $\mathrm{H} 0)$ the Fisher test (i.e. Fisher's combined probability test Equation 1) was used. Statistical analyses were carried out with the help of SPSS.

$$
X_{2 k}^{2} \sim-2 \sum_{i=1}^{k} \ln \left(p_{i}\right)
$$

The test comprises two steps. First, based on the Fisher form, the chi-square value $X^{2}$ is calculated as the sum of the natural logarithms of $k$-values multiplied by -2 . Then from the probability distribution of the chi-square value, considering $2 k$ degrees of freedom, the combined $p$ is derived.

The three methodological segments form an open research framework, where the results of the first step allow for a variety of possible continuations. This could be the evaluation of e-government projects, benchmarking the analysis of chosen projects, analysing the efficiency of organisational units, sectors, communities, regions, or states, or analysing the attitude and practice of the responsible professionals towards qualified evaluations of e-government projects. The later issue is the main challenge of our research covered by the latter two methodological segments.

\section{Presentation of the Results}

The study was a part of a broader research project which considered the whole e-government project life cycle. From the three phases of the projectcontrolling cycle (ex-ante evaluation, operational control, and ex-post evaluation) the reserach question under consideration addresses ex-ante evalution. This put the focus of the study on this specific project phase and encouraged the development of a tailored solution supporting development and improvement in ex ante evalutaion of e-government projects.

\subsection{Definition of the Parameters}

As mentioned before, the starting point in the study was the extended list of potential parameters. A review of the literature reveals at least ten approaches to the ex-ante (and ex-post) evaluation of e-government projects and services (Table 1). These are developed either at the conceptual or applicative levels. The majority of approaches are designed around the parameters of costs, benefits, and risks. On the basis of these approaches and the related literature, the focus group was conducted with two representatives of decisionmakers from the Ministry of Public Administration and two representatives of academia (the field of e-government). The aim of the focus group was to define the main parameters required for qualified ex-ante evaluation of e-government services. 13 such parameters were selected by the participants of the focus group. These parameters are the indicators used in order to measure the construct of ex-ante evaluation in the research model proposed in this paper. They are: 
- the costs of planning (labour costs related to an analysis of the current situation, planning, preparation, and execution of a public tender);

- the costs of development;

- the costs of implementation (equipment costs and costs related to organizational change - e.g. the costs of re-organization, management, research, and development);

- the costs of operation (e.g. the costs of the organization's own staff when the service is in operation, training costs, operational material costs, maintenance costs);

- source of project financing (the possibility of grants);

- the benefits for external users - citizens, businesses, $\mathrm{NGOs}^{3}$ (time and financial savings, easier decision-making);

- the benefits for internal users - public administration employees/ organizations (time and financial savings, an increase in solved cases, an increase in employee satisfaction, a decrease in their workload, better decision-making, improved communication/collaboration, fewer user complaints, fewer mistakes at work);

- the strategic and political benefits (e.g. alignment with the strategic plans of the organization, the Slovenian public administration and/or of the European Union, normative commitment to the implementation, etc.);

- general and other benefits (a lower level of corruption, a higher level of transparency, a more accountable public administration, the development of socially important areas);

- realization risk (due to the technological complexity of development and implementation);

- political risk (a lack of political support);

- organizational risk (due to the organizational complexity of development - e.g. the participation of multiple organizations);

- usability of the services (i.e. the results of the projects) in terms of their integrity, design following users' life events, multi-channel supply etc.

3 Non Governmental Organisations. 
Table 1: Review of the selected approaches to evaluating e-government projects (first-level parameters and number of all parameters)

\begin{tabular}{|c|c|c|}
\hline Approaches & First-level parameters & $\begin{array}{l}\text { Number of } \\
\text { parameters }\end{array}$ \\
\hline $\begin{array}{l}\text { MAREVA } \\
\text { (ADAE, 2007) }\end{array}$ & $\begin{array}{l}\text { - State financial value } \\
\text { - Direct customer value } \\
\text { - Risk } \\
\text { - Public services social \& operational value } \\
\text { - Project necessity }\end{array}$ & $>90$ \\
\hline $\begin{array}{l}\text { WiBe } \\
\text { (Röthig, 2004) }\end{array}$ & $\begin{array}{l}\text { - Economic efficiency in the monetary } \\
\text { sense (profitability) } \\
\text { - External effects } \\
\text { - Qualitative and strategic importance } \\
\text { - Urgency }\end{array}$ & 88 \\
\hline $\begin{array}{l}\text { DAM \& VAM } \\
(\text { AGIMO, 2004) }\end{array}$ & $\begin{array}{l}\text { - Costs } \\
\text { - Benefits } \\
\text { - Risks } \\
\text { - Demand assessment }\end{array}$ & 174 \\
\hline $\begin{array}{l}\text { eGEP } \\
\text { (eGEP, 2006b) }\end{array}$ & $\begin{array}{l}\text { - Costs } \\
\text { - Benefits (Effects) } \\
\text { - Risks }\end{array}$ & 149 \\
\hline $\begin{array}{l}\text { EU-VAST } \\
\text { (European Commission, } \\
\text { 2001) }\end{array}$ & $\begin{array}{l}\text { - Costs } \\
\text { - Benefits for the EU } \\
\text { - Benefits for the European Commission } \\
\text { - Financial costs and benefits } \\
\text { - Risks } \\
\text { - Urgency }\end{array}$ & 168 \\
\hline $\begin{array}{l}\text { VMM } \\
\text { (OGC, 2003) }\end{array}$ & $\begin{array}{l}\text { - Costs } \\
\text { - Benefits } \\
\text { - Risks } \\
\end{array}$ & 64 \\
\hline $\begin{array}{l}\text { Kertesz } \\
\text { (Kertesz, 2003) }\end{array}$ & $\begin{array}{l}\text { - Costs } \\
\text { - Benefits } \\
\text { - Risks } \\
\end{array}$ & 59 \\
\hline $\begin{array}{l}\text { Datar } \\
\text { (Datar, 2010) }\end{array}$ & $\begin{array}{l}\text { - Citizens' perspective } \\
\text { - Organizations' perspective } \\
\text { - Stage wise costing parameters }\end{array}$ & 33 \\
\hline
\end{tabular}

Source: own, based on sources listed in the table

\subsection{Questionnaire}

The second research step was the definition and the development of the questionnaire. Its core content is based on the results of the first research step and consists of 13 statements in 4 groups which follow the 13 parameters of qualified ex-ante e-government project evaluations. Survey participants were asked to assess their level of agreement with statements related to the measurement of the above-listed evaluation parameters, which were defined as crucial for qualified evaluation. The statements are presented in Table 2.

The second part of the questionnaire deals with the question of how well the public sector professionals are familiar with the methods for the evaluation of projects and how common the use of the methods is in practice. It consists of 3 questions about the knowledge of methods for evaluating the projects and 4 questions about the use of suitable methods. The statements are presented in Table 3. 
Participants respond to the statements with their level of agreement on the 7-point scale: completely disagree, mostly disagree, somewhat disagree, neither agree nor disagree, somewhat agree, mostly agree, completely agree.

The last part of the questionnaire gathers facts about the type of organisation (municipalities, ministries, affiliated bodies), the age of respondents, the duration of employment in public administration, the level of the respondents' influence on decisions, and the level of knowledge of the decision-making process. This makes it possible to analyse the quality of data regarding the role and structure of the pool of respondents.

\subsection{Survey Research Results}

The survey was conducted in January 2011, and the data were collected for one month. It was answered by 51 respondents, representing a 19\% response rate. Most respondents (68\%) were from municipalities, followed by those from ministries (18\%) and their affiliated bodies (14\%). The sample is biased to municipalities, however $19.6 \%$ of municipalities have more than 10,000 inhabitants, so over $50 \%$ of units are ministries, affiliated bodies and bigger municipalities. Beside that, the Mann Whitney test for two independent samples confirmed statistical signifant differences between two groups of organisation (ministries and affiliates, municipalities) only for one out of 20 variables of survey.

$86 \%$ of the respondents were older than 34 , and most of them (88\%) had been employed in public administration for 5 years or more, which indicates good knowledge of the way public administration functions. The respondents have a relatively significant impact on decisions regarding the realization of e-government projects in their organizations (with an average score of 5 on a 1-7 scale), and the same holds true for their knowledge of the decisionmaking process in the realization of such projects in their bodies (average score 5). Therefore, it can be deemed that, despite the low response rate (19\%), the responses gathered are of relatively high quality.

The presentation of the survey results is based on the descriptive statistics. The statistical significance of the differences between groups of parameters and between knowledge and use of suitable evalutation methods was tested by the paired t-test (McDonald, 2009, p. 180).

The aggregated results of the level of ex-ante evaluation of e-government projects in the Slovenian public sector (Graph 1) show a very high level of the frequency of the use of ex-ante evaluation amongst respondents. 


\section{Graph 1: Ex-ante evaluation of (aggregated) four groups of parameters in Slovenian public administration}

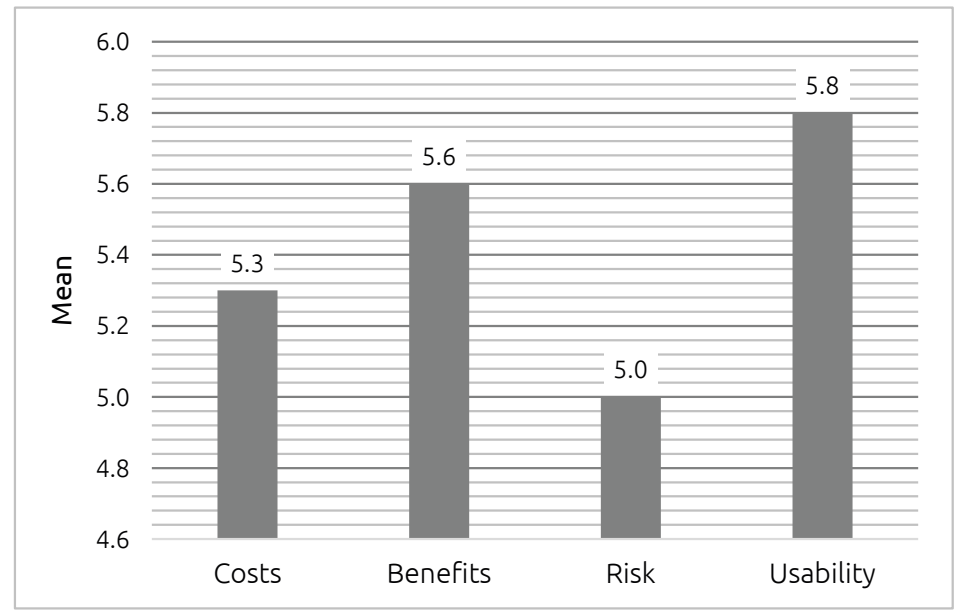

Source: own

Somewhat suprisingly the scores for usability and benefits are on the top of the standings, where the differences between the two are statistically insignificant (paired t-test, $p=0.098$ ). Both are an important factor driving the extent of the use of e-government services, although the researchers report that in general the use of e-government services does not meet expectations (Kumar, Mukerji, Butt, \& Persaud, 2007). The other 2 factors of exante evalutions costs and risks are valued significantly lower (paired t-tests, $p<0.005$ ), with statistically insignificant differences between them (paired t-test, $p=0.085$ ). The results express the quite common characteristic of public servants' attitudes, where the consideration of risks and costs is often overlooked.

The respondents value most aspects of the ex-ante evaluation of benefits nearly as highly as usability, while the consideration of strategic and political benefits takes a slighltly lower range (Table 2). Along with the lowest-scored aspect of the risks, consideration of the political risk (political support for the project), a lack of strategical and political consideration could be concluded. This phenomenon is characteristic for less-developed environments and diminishes the effectiveness and efficiency of e-government. Considering the evaluation of costs, the interresting fact is that the aspect of evaluating financing sources takes the top score, way above the ex-ante evaluations of various kinds of costs. The lowest score for risk evaluation supports the assumption that in the public sector the importance of considering projects' cost and risk issues is neglected. 


\section{Table 2: Measurement of parameters required for qualified evaluation of} e-government projects

\begin{tabular}{|c|c|}
\hline $\begin{array}{l}\text { Please express your level of agreement with the following statements about } \\
\text { the evaluation of various cost categories when deciding about the realization } \\
\text { of e-government projects in your organization. }\end{array}$ & Average \\
\hline $\begin{array}{l}\text { When we conduct ex-ante evaluation, we always consider the costs of } \\
\text { planning (the costs of employees related to an analysis of the current } \\
\text { situation, planning, preparation, and execution of a public tender). }\end{array}$ & 5.06 \\
\hline $\begin{array}{l}\text { When we conduct ex-ante evaluation we always consider the costs of } \\
\text { development. }\end{array}$ & 5.22 \\
\hline $\begin{array}{l}\text { When we conduct ex-ante evaluation we always consider the costs of } \\
\text { implementation (the costs of equipment and costs related to organizational } \\
\text { change-e.g. the costs of re-organization, management, research, and } \\
\text { development). }\end{array}$ & 5.18 \\
\hline $\begin{array}{l}\text { When we conduct ex-ante evaluation we always consider the costs of } \\
\text { operation (e.g. the costs of the organization's own staff when the service is in } \\
\text { operation, training costs, operational material costs, maintenance costs). }\end{array}$ & 5.24 \\
\hline $\begin{array}{l}\text { When we conduct ex-ante evaluation we always consider the source of project } \\
\text { financing (the possibility of obtaining grants). }\end{array}$ & 5.63 \\
\hline \multicolumn{2}{|l|}{$\begin{array}{l}\text { Please express your level of agreement with the following statements about } \\
\text { evaluation of different benefits categories when deciding about realization of } \\
\text { e-government projects in your organization. }\end{array}$} \\
\hline $\begin{array}{l}\text { When we conduct ex-ante evaluation we always consider benefits for external } \\
\text { users - citizens, businesses, NGOs (time and financial savings, easier decision- } \\
\text { making). }\end{array}$ & 5.78 \\
\hline $\begin{array}{l}\text { When we conduct ex-ante evaluation we always consider benefits for internal } \\
\text { users - public administration employees/organizations (time and financial } \\
\text { savings, an increase in solved cases, an increase in employee satisfaction, a } \\
\text { decrease in their workload, better decision-making, improved communication/ } \\
\text { collaboration, fewer user complaints, fewer mistakes at work). }\end{array}$ & 5.75 \\
\hline $\begin{array}{l}\text { When we conduct ex-ante evaluation we always consider strategic and } \\
\text { political benefits (e.g. alignment with the strategic plans of the organization, } \\
\text { the Slovenian public administration and/or of the European Union, normative } \\
\text { commitment to the implementation, etc.). }\end{array}$ & 5.24 \\
\hline $\begin{array}{l}\text { When we conduct ex-ante evaluation we always consider general and other } \\
\text { benefits (a lower level of corruption, a higher level of transparency, a more } \\
\text { accountable public administration, the development of socially important } \\
\text { areas). }\end{array}$ & 5.69 \\
\hline \multicolumn{2}{|l|}{$\begin{array}{l}\text { Please express your level of agreement with the following statements about } \\
\text { evaluation of different risk categories when deciding about the realization of } \\
\text { e-government projects in your organization. } \\
\text { When ex-ante evaluation of e-government projects in our organization is } \\
\text { conducted, we ... }\end{array}$} \\
\hline $\begin{array}{l}\text { always consider the realization risk (technological complexity of development } \\
\text { and implementation). }\end{array}$ & 5.24 \\
\hline always consider the political risk (political support for the project). & 4.57 \\
\hline $\begin{array}{l}\text { always consider the organizational risk (organizational complexity of } \\
\text { development - e.g. the participation of multiple organizations). }\end{array}$ & 5.31 \\
\hline \multicolumn{2}{|l|}{ Please, assess your agreement with the following statement. } \\
\hline $\begin{array}{l}\text { When deciding about the realization of e-government projects, our } \\
\text { organization always considers the usability of the services (i.e. the results of } \\
\text { the projects) in terms of their integrity, design following users' life events, } \\
\text { multi-channel supply, etc. }\end{array}$ & 5.80 \\
\hline
\end{tabular}

Source: own

The answers to the second part of the questionnaire show considerably different facts. The aggregated scores of knowledge and use of suitable methods (Graph 2) are significantly lower than the scores of ex-ante 
evaluation parameters. A closer look at the individual questions reveals that the respondents feel a lack of knowledge of information about projects and investment project evaluation methods. Unsurprisingly the same holds for the use of the methods, where the result is even slightly worse, but the difference is not statistically significant (t-test, $p=0.219$ ).

\section{Graph 2: Knowledge and use of suitable methods for project evaluation}

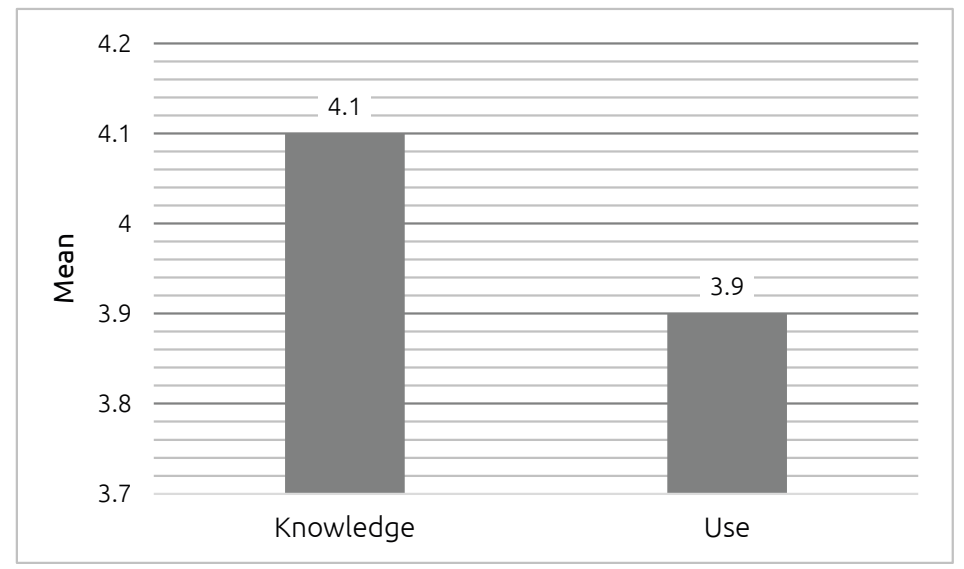

Source: own

A closer insight to the individual statements (Table 3) reveals that only the knowledge of standard methods for evaluating investment projects achieves higher score slightly under 5 but all other statements achieve scores slightly about 4. The lowest scores go to the use of advanced methods for evaluating $\mathrm{ICT}^{4}$ projects and to the knowledge and use of methods for evaluation thereof.

Table 3: Measurement of knowledge and use of methods for evaluation of e-government projects

\begin{tabular}{|l|c|}
\hline Our organisation is well known with: & Average \\
\hline Standard methods for evaluating investment projects. & 4.79 \\
\hline Advanced methods for evaluating investment projects. & 4.06 \\
\hline Methods for evaluating ICT projects. & 3.86 \\
\hline Our organisation always applies: & 4.13 \\
\hline Standard methods for evaluating investment projects. & 3.43 \\
\hline Advanced methods for evaluating investment projects. & 4.06 \\
\hline Standard methods for evaluating investment projects for ICT projects. & 3.78 \\
\hline Methods for evaluating ICT projects. & \\
\hline
\end{tabular}

Source: own

Based on the descriptive statistics, the following conclusions can be drawn: among four groups of evaluation parameters, usability is the one most frequently taken into consideration within ex-ante evaluation of e-government projects in Slovenian public administration, followed by benefits and costs,

4 Information Communication Technology. 
while risks are considered least often (Graph 1). The scores are considerably higher than 5, whichallows us to claim thatrespondents believe thatin Slovenian public administration qualified evaluations of e-government projects are in place. However, the scores of the second part of the questionnaire about the knowledge and use of suitable methods for evaluating investment projects and specifically ICT projects show a quite different picture. The respondents' enthusiasm with e-government project evaluations is not supported by an eligible level of the use of suitable evaluation methods.

\subsection{Research Question}

The research question "Are qualified evaluations of e-government projects conducted in Slovenian public administration?" could be answered positively only if the scores of the both part of the questionnaire could be proven to be significantly higher than the expected margin. As we mentioned before, all statements under consideration have the same 7 point-measurement scale of agreement, where the lowest value expressing positive agreement is 6 (mostly agree). Taking into account the use of Fisher's combined test for testing the level of agreement with the statements, instead of the central point of the scale (4) the cut point of 5 was chosen. The robustness analysis showed that a lower cut point would drive us to the same conclusions.

Along with the analysis of two different views of e-government project evaluation processes, the question is tested with 2 hypotheses, where the positive answer to the question is confirmed only if both hypotheses are proven to be true:

In Slovenian public administration

H1: Qualified evaluations of e-government projects are carried out on a regular basis; and

H2: Evaluations of e-government projects are supported by at least standard evaluation methods.

$\mathrm{H} 1$ testing considers 13 statements from Table 2. As we mentioned before the statistical tests take two steps. The first step is a nonparametric binomial test with the cut point of 5 , and proportion 0.50 . This way 1 -tailed $p$-values were calculated for each statement under consideration (Table 4). Since there are $13 \mathrm{p}$-values, but one meta value is required in order to uniquely address the research question, a Fisher test (i.e. Fisher's combined probability test) was used as follows: the chi-square $p$-value was calculated via two steps: first, based on the Fisher form, the sum of the natural logarithms of $p$-values in Table 4 has been calculated and multiplied by -2 with the result $X^{2}=69.90$ with a degree of freedom $d f=26$. Then, the probability distribution of the chi-square was calculated. The resulting $p$-value was $<0.000$, indicating high statistical significance. Consequently the null hypothesis that the proportion of the answers 5 or lower is higher than 0.50 can be rejected. 
Table 4: P-values - H1

\begin{tabular}{|l|c|}
\hline Cut point $=5$ & $\begin{array}{c}\text { p-values } \\
\text { (1-tailed) }\end{array}$ \\
\hline Ex-ante evaluation parameters & 0.610 \\
\hline costs of planning & 0.288 \\
\hline costs of development & 0.500 \\
\hline costs of implementation & 0.288 \\
\hline costs of operative functioning & 0.001 \\
\hline source of financing & 0.002 \\
\hline benefits for external users & 0.005 \\
\hline benefits for internal users & 0.712 \\
\hline strategic \& political benefits & 0.024 \\
\hline social benefits & 0.610 \\
\hline execution risk & 0.999 \\
\hline political risk & 0.712 \\
\hline organizational risk & 0.000 \\
\hline usability of services
\end{tabular}

Source: own

This confirms the atternative hypothesis that the proportion of the answers with a score greater than 5 is greater than 0.50 and indicates that ex-ante evaluations of e-government projects in Slovenian public administration meet the requirements of qualified evaluations as defined by the 13 parameters in chapter 4.1.

For the second hypothesis, only 2 variables had to be tested. The proportions of the scores 5 and lower are greater than 0.50 for both variables. The $p$ values for the both variables expressing the level of the use of standard evaluation methods (the first and third statement in the second part of the Table 3) are 0.999 and 1.000. The proportions of the scores 5 or lower are for both variables significantly higher than 0.50 , consequently the null hypothesis that the proportion of the scores 5 or lower is higher than 0.5 must be retained. The alternative hypothesis that the proportion of the scores higher than 5 is higher than 0.50 must be rejected. That indicates that evaluations of e-government projects in Slovenian public administration are not supported even by at least standard evaluation methods.

The first hypothesis: that qualified evaluations of e-government projects are carried out on regular basis was confirmed; and the second hypothesis: that evaluations of e-government projects are supported by at least standard evaluation methods was rejected.

The answer to the research question "Are qualified evaluations of e-government projects conducted in Slovenian public administration?" is negative. Organizations of Slovenian public administration do conduct ex-ante evaluations of e-government projects along the 13 core parameters, however their efforts are not supported by even standard evaluation methods. 


\section{Discussion and Conclusion}

In this paper, 13 parameters needing to be measured in order to conduct qualified evaluations of e-government projects were identified. These parameters were defined as a consensus among the focus group participants who have practical and academic experience. This set of parameters may be used in countries with a low level of evaluation culture - in countries where evaluation has not yet become an equitable phase of project life cycle. Namely, in these countries, approaches with dozens of parameters are not of great value. This is due to the lack of project management mechanisms enabling identification and proper recording of project costs and other relevant parameters. When in these countries first evaluations are conducted, it usually proves that data sources are rarely known (i.e. the sources of values of parameters to be measured). Thus, a short set of parameters represents a useful tool in the initial evaluation efforts.

Furthermore, using the above-mentioned set of 13 evaluation parameters, supplemented by additional statements about the kowledge and use of suitable project evalution methods, a questionnaire for quick assessment of the status quo in qualified (ex-ante) evaluation of e-government projects in choosen enviroment (country, region, public sector field, etc.) was developed. This enables decision-makers to assess the situation and develop measures for improvement.

The survey within Slovenian public administration proves the usefulness of the measurement instrument. Using a binomial statistical test and Fisher's combined probability test, it was established that in Slovenian public administration qualified evaluation of e-government projects are not being conducted. It is interesting that public servants responsible for e-government projects assess the level of ex-ante evaluations as rather high. By their assessment, qualified evaluations are in place. Notwithstanding the result of the second part of the questionaire about knowledge and use of suitable evalution methods, it was revealed that the evaluations do not comprise the methodological corectness.

This is not surprising, as in Slovenia no formal evaluation method is used when selecting the projects to be included in the four-year e-government action plan; the ministries are asked to propose e-government projects, but there is no "permanent" method or tool used to evaluate (or select) their suggestions. This indicates that the extent of the evaluation methodology in terms of the number of parameters measured does not necessary reflect its success. The case of Slovenian public administration revealed that to conduct (ex-ante) evaluations without considering their quality is insufficient, and the outcomes depend strongly on the presence of a systematic framework comprising suitable evaluation methods. 
In addition, the results revealed that when, in Slovenian public administration, evaluations of e-government projects are conducted, they focus more on usability and benefit parameters than on costs and risks. On the one hand, this indicates that user-centricity is the leading principle of e-government development in Slovenia. This might be due to the mostly qualitative nature of these parameters, indicating that their values are more easily gathered compared to various types of costs. However, future research might investigate further why the evaluation of risks is underestimated. Nevertheless, we are facing tremendous pressure on grounded public expenditure. Principles such as accountability and transparency are becoming the main guideline of work in the public sector - next to well-established efficiency and effectiveness. A serious, critical approach to evaluating e-government projects certainly does mean a step towards realizing these and other principles of the public sector's contemporary operation.

Jože Benčina is an associate professor in the field of public sector economics at the Faculty of Public Administration, University of Ljubljana. He holds a PhD in Economics from the University of Ljubljana in the field of management information systems. He researches and develops methods for measuring the performance of the public sector and the methods to optimize decision-making in the public sector, supported by fuzzy logic. Currently, most of the time, he dedicates to factorization methods for the development of aggregated indicators for measuring the quality of public governance.

Tina Jukić gained her PhD in Administrative science in 2012 at Faculty of Public Administration, University of Ljubljana, Slovenia. Since 2006, she is employed at the same faculty, where she is a teacher and researcher in the field of informatics in public sector. She is also a coordinator of the eGovernment working group within the NISPAcee conference. Her research activities are predominantly focused on various viewpoints of e-government, lately manly on evaluation of e-government projects and policies, as well as content analysis of the e-government research. 
Jože Benčina, Tina Jukić

\section{References}

ADAE (2007). MAREVA methodology guide: Analysis of the value of ADELE projects, Fourth High Level Seminar on Measuring and Evaluating E-Government. Dubai.

AGIMO - Australian Government Information Office (2004). Demand and Value Assessment Methodology. Canberra: Commonwealth of Australia.

Castelnovo, W., \& Simonetta, M. (2007). The Evaluation of e-Government projects for Small Local Government Organisations. The Electronic Journal of e-Government, 5(1), 21-28.

Cracknell, B. E. (2000). Evaluating Development Aid: Issues, Problems and Solutions. New Delhi, Thousand Oaks, London: Sage.

Datar, M. (2010). Determining Priorities of E-Government: A Model Building Approach. ICEG 2010 - 6th International Conference on eGovernment - Cape Town, South Africa (pp. 76-85).

eGEP - eGovernment Economics Project. (2006a). Expenditure Study Final Version. DG Information Society and Media, European Commission.

eGEP - eGovernment Economics Project. (2006b). Measurement Framework Final Version. DG Information Society and Media, European Commission.

European Commission. (2011). Value Assessment Tool Guidelines. Brussels: European Commission.

Heeks, R. (2012). Steering e-Government Projects from Failure to Success. Retrieved 10. 9. 2012, from http://ict4dblog.wordpress.com/category/e-government-in$\mathrm{dcs} /$

Homburg, V. (2008). Understanding E-government: Information Systems In Public Administration. Abingdon: Routledge.

Jukić, T., \& Benčina, J. (2015). Vpliv predhodnega vrednotenja projektov e-uprave na njihovo uspešnost. Uporabna informatika, 23(1), 3-13.

Kertesz, S. (2003). Cost-Benefit Analysis of e-Government Investments. Cambridge: Harvard University, J.F. Kennedy School of Government.

Kumar, V., Mukerji, B., Butt, I., \& Persaud, A. (2007). Factors for Successful e-Government Adoption: a Conceptual Framework. The Electronic Journal of e-Government, 5(1), 63-76.

Kustec Lipicer, S. (2002). Evalvacija ali vrednotenje javnih politik. In: D. FinkHafner \& D. Lajh (Eds.), Analiza politik (pp. 141-156) (Knjižna zbirka Politični procesi in inštitucije), (Knjižna zbirka Profesija). Ljubljana: Faculty of social sciences.

McDonald, J. H. (2009). Handbook of Biological Statistics. Baltimore: Sparky House Publishing.

Nograšek, J., Stanimirović, D., Jukić, T., \& Vintar, M. (2012). Razvoj integralnega modela kazalnikov za evalvacijo politik na področju e-uprave. Uporabna informatika, 20(4), 218-228.

OGC. (2003). Measuring the Expected Benefits of e-Government. Retrieved 17. 5. 2010, from http://www.publicnet.co.uk/abstracts/2003/10/20/measuringthe-expected-benefits-of-e-government/

Rana, N. P., Dwivedi, Y. K., \& Williams, M. D. (2013). Analysing challenges, barriers and CSF of egov adoption. Transforming Government: People, Process and Policy, 7(2), 177-198. DOI: 10.1108/17506161311325350

Remenyi, D. (1999). IT Investment: Making a Business Case. Burlington: Butterworth-Heinemann. 
Röthig, P. (2004). WiBe 4.0: Recommendations on Economic Efficiency Assessments in the German Federal Administration, in Particular with Regard to the Use of Information Technology, Version 4.0 - 2004. Weimar: KBSt Publication Series.

Stanimirović, D., Jukić, T., Nograšek, J. \& Vintar, M. (2012). Analysis of the Methodologies for Evaluation of E-Government Policies. In: H. J. Scholl (Ed.), Electronic Government: Proceedings (pp. 234-245).

DOI: 10.1007/978-3-642-33489-4_20

Thomas, G., Seddon, P. B., \& Fernandez, W. (2008). IT project evaluation: Why more formal evaluation is not necessarily better? In: Z. Irani \& P. Love (Eds.), Evaluating Information Systems - Public and Private Sector (pp. 78-98). Oxford, UK: Elsevier Ltd. DOI: 10.1016/B978-0-7506-8587-0.50008-1

Todorovski, L., Jukić, T., Leben, A., \& Vintar, M. (2014). Catalogue of Indicators for Evaluating E-Government Policies. In: Government vs. Governance in Central and Eastern Europe : from pre-Weberianism to neo-Weberianism? Budapest: NISPAcee.

Yildiz, M. (2007). E-government research: Reviewing the literature, limitations, and ways forward. Government Information Quarterly, 24(3), 646-665.

DOI: $10.1016 /$ j.giq.2007.01.002 


\section{Kako oceniti, ali v slovenski javni upravi izvajajo kvalificirane evalvacije projektov e-uprave? Primer v Sloveniji}

V zadnjih 15 letih so države investirale znatna sredstva v razvoj e-uprave. Vendar doseženi rezultati niso upravičili pričakovanj. Odločitve o prioritetah razvoja in implementacije so pogosto slabo utemeljene in podvržene lobiranju. Zato so nekatere države že razvile pristope za evalvacijo projektov e-uprave, nekatere med njimi upoštevajo preko sto evalvacijskih parametrov. Tak pristop je smiseln v državah z visoko razvito kulturo evalvacije. V državah s slabše uveljavljeno evalvacijsko kulturo pa je prav gotovo bolje začeti z manj kompleksnimi evalvacijami, ki upoštevajo manjše število parametrov, in tako opredeliti kvalificirano evalvacijo ko učinkovito orodje, ki upošteva ključne razvojne izzive e-uprave v takem okolju.

Prispevek išče odgovor na raziskovalno vprašanje: Ali v slovenski javni upravi izvajajo kvalificirane evalvacije projektov e-uprave?

Iskanje odgovora na vprašanje je podprto s štirim cilji:

- predstaviti obstoječe pristope k evalvaciji projektov e-uprave,

- opredeliti parametre kvalificirane evalvacije projektov e-uprave,

- razviti vprašalnik za oceno stanja glede kvalificiranih evalvacij projektov e-uprave in

- predstaviti izvedbo in rezultate anketne raziskave o stanju na tem področju v slovenski javni upravi.

Na osnovi splošne definicije lahko definiramo evalvacijo projektov e-uprave kot proces pridobivanja informacij, s katerimi podpremo odločanje o realizaciji projektov oziroma implementaciji storitev e-uprave. S stališča izziva, ki ga obravnava pričujoči prispevek, je ključen trenutek ocenjevanja. S predhodno evalvacijo ocenjujemo potencialne alternativne rešitve in njihove učinke na osnovi ocene stroškov, koristi učinkov, priložnosti in izzivov. Naknadna evalvacija preverja, ali so pričakovani cilji v opazovanih vidikih doseženi. Pri tem je eden od ključnih vidikov povratna zanka z naknadne na predhodno evalvacijo in preverjanje njene ustreznosti.

Metodologija je bila izbrana glede na postavljene raziskovalne cilje v treh segmentih:

- parametri kvalificirane evalvacije projektov e-uprave,

- vprašalnik za oceno stanja na področju evalvacij projektov e-uprave in

- anketna raziskava v slovenski javni upravi. 
Parametre kvalificirane evalvacije projektov e-uprave smo definirali v treh korakih. Prvi korak je bila analiza obstoječih pristopov in opredelitev širšega nabora parametrov. Nato je fokusna skupina dveh predstavnikov Ministrstva za javno upravo in dveh predstavnikov raziskovalcev s tega področja z uporabo Delphi postopka za usklajevanje pogledov v štirih korakih določila nabor ključnih parametrov za kvalificirano evalvacijo projektov e-uprave.

To je bila osnova za oblikovanje vprašalnika v obliki trditev, na katere se je bilo mogoče odzvati s sedmimi stopnjami (ne) strinjanja (od »sploh se ne strinjam« do »popolnoma se strinjam«). Vprašalnik meri strinjanje anketirancev o tem, kako dobro so seznanjeni z izbranimi metodami, ki so del kvalificirane evalvacije projektov e-uprave in kako pogosta je uporaba le teh v praksi.

Anketna raziskave je bila izvedena s pomočjo spletnega orodja Survey System 9.0. Populacija je obsegala 266 organizacij, to so bila ministrstva (15), agencije (40) in občine (211). Povabilo k anketi je bilo razposlano na ustrezne naslove odgovornih oseb v izbranih organizacijah.

V statistični obdelavi so bile uporabljene ustrezne metode opisne statistike. Odgovor na raziskovalno vprašanje smo poiskali s pomočjo ustrezne hipoteze. Vrsta hipoteze in majhen vzorec sta bila razlog za uporabo neparametričnega binomialnega testa. Ker se preverjanje ničelne hipoteze nanaša na več posamičnih neodvisnih testov, smo za končno oceno hipoteze uporabili Fisherjev kombinirani test verjetnosti. Pri tem smo najprej na osnovi Fisherjeve formule izračunali vrednost X2 kot vsoto logaritmov $p$-vrednosti vseh posamičnih testov pomnoženo $z-2$ in nato, upoštevaje, da imamo $2 k$ prostostnih stopenj, izračunali $p$-vrednost kombiniranega testa.

Študija, katere del rezultatov predstavljamo v pričujočem prispevku, se nanaša na celoten življenjski cikel projektov. Z raziskovalnim vprašanjem smo se v naši študiji omejili na prvi korak, predhodno evalvacijo in ustrezne pramatere.

S pomočjo predhodno že omenjenega raziskovalnega postopka smo ob sodelovanju ekspertov izbrali omejen nabor 13 evalvacijskih parametrov: stroški načrtovanja, stroški razvoja, stroški implementacije, stroški delovanja, viri projekta, koristi za zunanje uporabnike (stranke), koristi za notranje uporabnike (zaposleni, organizacije javne uprave), strateške in politične koristi, splošne in druge koristi, tveganja izvedbe projekta, politična tveganja, organizacijska tveganja in uporabnost e-storitev.

Izbrani parametri so bili osnova za oblikovanje vprašalnika, ki je dvodelen. Prvi del vprašalnika sestavlja 13 trditev, ki se nanašajo za izbrane parametre predhodne evalvacije projektov e-uprave in merijo stopnjo strinjanja anketirancev o tem, da pri odločanju vedno upoštevajo parametre kvalificirane predhodne evalvacije projektov e-uprave. Drugi del vprašalnika pa se nanaša na metode za evalvacijo projektov e-uprave. Tri vprašanja se nanašajo na poznavanje teh metod, štiri pa na dejansko uporabo teh metod v evalvacijah. 
Anketna raziskava je bila izvedena januarja 2011. Od 266 organizacij v vzorcu, se jih je odzvalo 51, kar pomeni 19-odstotno odzivnost. Struktura vzorca izkazuje $68 \%$ občin, $18 \%$ ministrstev in $14 \%$ organov v sestavi ministrstev. Več kot tretjina občin, ki so se odzvale (19,6 odstotnih točk) ima več kot 10.000 prebivalcev, zato je v vzorcu več kot polovica enot, v katerih gre za večji obseg in doseg delovanja. Morebitna pristranost vzorca nima statistične značilnosti, saj Mann Whitneyev test za 2 neodvisna vzorca potrjuje statistično značilne razlike med dvema skupinama (ministrstva in organi v njihovi sestavi, občine), samo pri eni spremenljivki, ki pa ni vključena v preverjanje hipoteze.

Rezultati dela ankete, kjer ugotavljamo pogostost uporabe, so pokazali, da je uporaba predhodne evalvacije v slovenski javni upravi kar pogosta, saj so aritmetične sredine agregiranih rezultatov za stroške, koristi, tveganja in uporabnost vse večje ali enake 5, karje za celo točko več od srednje vrednoti 4 na uporabljeni sedem mestni lestvici strinjanja. Pri tem je nekoliko presenetljivo, da je najvišjo oceno $(5,8)$ dobila ocena uporabnosti rešitev, saj je prav obseg uporabe ključna priložnost za izboljšanje e-uprave. Ob bok uporabnosti se je postavila ocena koristi $(5,6)$. Statistično značilno nižji sta oceni za stroške $(5,3)$ in tveganja (5,0), kar pa glede na način delovanja javnega sektorja niti ni tako presenetljivo. Pregled rezultatov po posameznih parametrih pokaže, da je agregirana ocena ocenjevanja stroškov nekoliko višja zaradi tega, ker je v tem sklopu precej višje ocenjeno vprašanje o ocenjevanju finančnih virov $(5,63)$. Pri koristih in tveganjih pa navzdol odstopata trditvi, ki se navezujeta na strateške in politične vidike $(5,24$ in 4,57), kar je lahko tudi eden od razlogov, da rezultati razvoja e-uprave ne dosegajo pričakovanj.

Oceni poznavanja $(4,1)$ in uporabe $(3,9)$ primernih metod za evalvacijo projektov e-uprave je bistveno nižja od ocene izvajanja ocenjevanja. Podrobnejši vpogled v posamezne trditve pokaže, da sta tako poznavanje kot uporaba standardnih metod za evalvacijo v slovenski javni upravi kar prisotna, medtem ko je stanje glede naprednejših in specializiranih metod znatno slabše. Lahko torej ugotovimo, da bi se bilo treba v okviru razvoja evalvacije projektov e-uprave v slovenski javni upravi osredotočiti predvsem na dvig znanja o naprednih metodah evalvacije.

Na raziskovalno vprašanje smo odgovorili s pomočjo preverjanja dveh hipotez:

- H1: Kvalificirane evalvacije projektov e-uprave se redno izvajajo.

- H2: Evalvacije projektov e-uprave so podprte vsaj z standardnimi metodami evalvacije.

Prva hipoteza se nanaša na prvih 13 spremenljivk, s katerimi so respondenti ocenili uporabo parametrov kvalificirane evalvacije projektov e-uprave. Druga hipoteza pa preverja uporabo standardnih metod evalvacije iz drugega dela vprašalnika.

Vse spremenljivke so ocenjene na lestvici od 1 do 7. Zaradi narave hipotez smo za njuno preverjanje uporabili neparametrični binomialni test. Prva hipoteza 
obsega neodvisno preverjanje 13 spremenljivk, zato nas do kočne ocene hipoteze pripelje Fisherjev kombinirani test verjetnosti, ki smo ga omenili že pri predstavitvi metod. Za točko preloma binomialnega testa smo vzeli vrednost 5 in tako pomaknili zahteve za pozitivno oceno za eno točko višje od srednje vrednosti lestvice.

Preverjanje ničelne hipoteze za hipotezo 1 je bilo izvedeno $v$ dveh korakih. Prvi korak je bil binomialni test, s katerim smo ničelno hipotezo, da ni več kot polovica anketirancev ocenila trditve z vrednostjo 5, zavrnili za 5 od 13 spremenljivk. Z uporabo Fisherjeve formule pa smo izračunali $p$ vrednost $<0,000$ in na ta način ničelno hipotezo za celoten sklop vprašanj zavrnili. Tako smo hipotezo, da se kvalificirane evalvacije projektov e-uprave redno izvajajo, potrdili.

Preverjanje druge hipoteze temelji na dveh spremenljivkah, ki merita uporabo standardnih metod za evalvacijo projektov e-uprave. Delež ocen 5 ali manj je v obeh primerih večji od 0,50. Binomialni test s točko preloma 5 za delež 0,50 je dal vrednosti 0,392 in 0,002, zato moramo pri obeh obdržati ničelno hipotezo, da je delež ocen 5 ali manj večji ali enak 0,50. Tako alternativno hipotezo, da je delež ocen večjih od 5 večji od 0,50 pri obeh spremenljivkah zavrnemo in na ta način ugotovimo, da v odločanje o projektih e-uprave v slovenski javni upravi ni podprto vsaj s standardnimi evalvacijskimi metodami.

Odgovor na raziskovalno vprašanje »Ali v slovenski javni upravi izvajajo kvalificirane evalvacije projektov e-uprave? « je zato negativen. Organizacije v slovenskem javnem sektorju sicer izvajajo predhodne evalvacije projektov e-uprave, vendar le-te niso podprte z vsaj standardnimi metodami za evalvacijo projektov.

Tako smo s pomočjo razvitega merskega instrumenta, z uporabo izbranih statističnih metod preverili stanje na področju evalvacije projektov e-uprave v slovenski javni upravi. Na ta način smo potrdili uporabnost instrumenta in ga s tem ponudili v uporabo tudi v drugih podobnih okoljih. Rezultati raziskave kažejo, da so priložnosti za izboljšanje v večji uporabi ustreznih metod za evalvacijo projektov. Odgovorni za razvoj e-uprave v slovenski javni upravi se zavedajo pomena evalvacij in le te praviloma tudi izvajajo. Izkazalo pa se je, da premalo pozornosti posvečajo metodološkemu okviru tako pri znanju udeleženih kot pri obsegu uporabe standardnih in tudi naprednih metod evalvacije. 